\title{
IFNG +874A/T Polymorphism Among Asymptomatic HTLV-1-Infected Individuals Is Potentially Related to a Worse Prognosis
}

\author{
Maria A. F. Queiroz*, Vânia N. Azevedo, Ednelza da S. G. Amoras, Tuane C. F. Moura, \\ Marluísa de O. Guimarães Ishak, Ricardo Ishak, Antonio C. R. Vallinoto and \\ Rosimar N. Martins Feitosa
}

Laboratory of Virology, Institute of Biological Sciences, Federal University of Pará, Belém, Brazil

OPEN ACCESS

Edited by:

Umberto Bertazzoni,

University of Verona, Italy

Reviewed by:

Graham Philip Taylor, Imperial College London,

United Kingdom

Guido Poli,

Vita-Salute San Raffaele University,

Italy

*Correspondence:

Maria A. F. Queiroz alicefarma@hotmail.com

Specialty section:

This article was submitted to

Virology,

a section of the journal

Frontiers in Microbiology

Received: 15 January 2018

Accepted: 09 April 2018

Published: 18 May 2018

Citation:

Queiroz MAF, Azevedo VN,

Amoras ESG, Moura TCF, Guimarães Ishak MOG, Ishak R,

Vallinoto $A C R$ and

Martins Feitosa RN (2018) IFNG

+874A/T Polymorphism Among

Asymptomatic HTLV-1-Infected Individuals Is Potentially Related to a Worse Prognosis.

Front. Microbiol. 9:795.

doi: 10.3389/fmicb.2018.00795
HTLV-1 infections are persistent and frequently latent; however, productive infections trigger different types of immunological responses that utilize cytokines to control infection. The present study investigated the role of IFNG +874A/T polymorphisms among 153 HTLV-1-infected individuals (33 clinically diagnosed with TSP/HAM, 22 with rheumatologic manifestations, 2 with dermatitis, 1 with uveitis, and 95 asymptomatic patients) and 300 healthy control individuals. Genotyping and proviral HTLV-1 load assessment were performed using real-time PCR assays, and the plasma levels of IFN- $\gamma$ were measured using an enzyme immunoassay (ELISA). Genotype frequencies were not significantly different, but the presence of the T allele was higher $(p<0.0142)$ among the asymptomatic patients. Plasma levels of IFN- $\gamma$ were significantly higher $(p<0.0137)$ among those with the $\Pi$ genotype. Their proviral load was also higher, although this elevation did not reach statistical significance. There was no difference in the IFN- $\gamma$ plasma levels among the symptomatic patients, even when ranked according to disease severity (TSP/HAM or rheumatologic manifestations). However, the difference among asymptomatic patients with the T allele was significantly higher $(p<0.0016)$ and similar to the plasma levels observed among symptomatic individuals. These results suggest that the IFNG +874A/T polymorphism may modulate the plasma levels of IFN$\gamma$ during HTLV-1 infection. Asymptomatic carriers of the polymorphic genotypes appear to develop an inflammatory response in a shorter timeframe, triggering progression to HTLV-1-related symptoms and disorders. These results further suggest that HTLV-1infected asymptomatic individuals expressing the IFNG +874A/T polymorphism should be monitored more closely in order to readily detect the increase in clinical symptoms, as these patients are potentially at risk of a poor prognosis and should therefore start available treatment procedures earlier.

Keywords: HTLV-1, IFN- $\gamma$, polymorphism, plasma dosage, clinical symptoms

\section{INTRODUCTION}

Human T-cell lymphotropic virus type 1 (HTLV-1) infects approximately 5-10 million people worldwide (Cassar and Gessain, 2017). The most relevant endemic regions are located in southeastern Japan, sub-Saharan Africa, the Caribbean, the Middle East, the Austro-Melanesia region, and South America (Gessain and Cassar, 2012). Brazil is an important endemic area for the 
virus, and a great diversity of diseases associated with HTLV-1 have been observed there (Pombo de Oliveira et al., 1999; Rathsam-Pinheiro et al., 2009; Grassi et al., 2011; Okajima et al., 2013). The prevalence of infection varies among different regions of the country: the southern region usually shows the lowest rates, and the northeast region shows the highest rates (Catalan-Soares et al., 2005).

Most HTLV-1 infections are asymptomatic; however, under certain conditions not yet fully understood, the virus may lead to the development of associated diseases, including HTLV-1associated myelopathy/tropical spastic paraparesis (HAM/TSP), adult T-cell leukemia/lymphoma (ATLL), and inflammatory syndromes such as rheumatoid arthritis, dermatitis, and uveitis (Yakova et al., 2005; Okajima et al., 2013; Quaresma et al., 2015). The development of symptoms, particularly those of HAM/TSP and rheumatoid arthritis, are associated with a high proviral load in the peripheral blood and dysregulation of the immunological response against the virus (Grassi et al., 2011; Coutinho et al., 2014; da Silva Dias et al., 2016). Several studies have investigated the mechanisms underlying how immunological factors may change the course of HTLV-1 infection (Goon et al., 2004; Kato et al., 2004; Yakova et al., 2005; Best et al., 2009; Araya et al., 2014; Coutinho et al., 2014). The virus induces spontaneous proliferation of $\mathrm{T} \mathrm{CD}^{+}$and $\mathrm{T} \mathrm{CD}^{+}$lymphocytes and natural killer cells (Goon et al., 2004; Pinto et al., 2011). The increases in the numbers of these cells may lead to the development of a hyperimmune response and the marked production of proinflammatory cytokines, contributing to the pathogenesis of inflammatory disorders associated with HTLV-1 (Montanheiro et al., 2009; Yamano et al., 2009).

Genetic variations in important components of the immunological system are associated with the presence of symptoms in HTLV-1 infection (Vallinoto et al., 2012; Shirdel et al., 2013; de Sá et al., 2016). IFN- $\gamma$ is the main proinflammatory cytokine associated with clinical symptoms etiologically linked to HTLV-1 infection (Montanheiro et al., 2009; da Silva Dias et al., 2016). The IFNG gene expresses CA-repeat microsatellite polymorphisms, and the major one-IFNG +874 A/T-is associated with the increased production of IFN- $\gamma$ (Pravica et al., 1999). The presence of this polymorphism has been associated with multiple viral infections, including HIV-1, hepatitis B virus (Freitas et al., 2015; Al Kadi and Monem, 2017) and susceptibility to HTLV-1 infection (Rocha-Júnior et al., 2012).

The direct influence of this polymorphism on IFN- $\gamma$ levels in HTLV-1-infected individuals has not reportedly been characterized. The marked inflammatory response observed with HTLV-1-associated diseases was therefore investigated in order to determine the influence of the IFNG $+874 \mathrm{~A} / \mathrm{T}$ polymorphism on the plasma level of IFN- $\gamma$ and its relationship with the progression of HTLV-1 infection to symptomatic disease.

\section{MATERIALS AND METHODS}

\section{Study Population}

This study examined 153 HTLV-1-infected individuals (33 clinically diagnosed with HAM/TSP, 22 with rheumatic manifestations, 2 with dermatitis, 1 with uveitis, and 95 asymptomatic individuals) of both sexes, older than 18 years, not currently being treated with glucocorticoids, who were followed in the outpatient clinic of the Tropical Medicine Division of the Federal University of Pará. Clinical and laboratory criteria were used to diagnose the diseases associated with HTLV-1 according to the Brazilian Guidelines for HTLV-1 diseases from the Brazilian Ministry of Health (Brasil. Ministério da Saúde, 2013). The control group consisted of 300 blood donors from the Center for Hemotherapy and Hematology of Pará (HEMOPA) who were used to compare the genotype and allele frequencies of the IFNG $+874 \mathrm{~A} / \mathrm{T}$ polymorphism. The control group was matched by age and sex with the HTLV-1-infected individuals.

\section{Collection and Storage of Samples}

Blood samples were collected $(10 \mathrm{~mL})$ by intravenous puncture using a vacuum collection system containing ethylenediaminetetraacetic acid (EDTA) as an anticoagulant. The samples were centrifuged at $3,000 \mathrm{rpm}$ for $10 \mathrm{~min}$ to separate the leukocytes. Leukocytes were used to extract genomic DNA for analysis of the IFNG $+874 \mathrm{~A} / \mathrm{T}$ polymorphism and quantification of the proviral load. Plasma samples were used for the quantification of IFN- $\gamma$. Samples were stored at $-70^{\circ} \mathrm{C}$ until use.

\section{Laboratory Tests DNA Extraction}

DNA was extracted from peripheral blood leukocytes using a Puregene kit (Puregene, Gentra Systems, Inc., United States) according to the manufacturer's protocol, which included cell lysis, protein precipitation, DNA precipitation, and hydration. After extraction, the DNA was quantified using a Qubit ${ }^{\circledR} 2.0$ fluorometer (Life Technologies, Carlsbad, CA, United States) and the Qubit ${ }^{\mathrm{TM}}$ DNA Assay Kit (Life Technologies, Carlsbad, CA, United States) reagents, following the manufacturer's protocol.

\section{Quantification of the Proviral Load of HTLV-1}

Proviral load was quantified by qPCR using three target sequences synthesized using the $\operatorname{TaqMan}^{\circledR}$ system (Life Technologies, Foster City, CA, United States), according to a previously described protocol by Tamegão-Lopes et al. (2006), namely, collection of $5 \mathrm{~mL}$ of whole blood for DNA extraction from leukocytes, followed by relative quantification using real-time PCR. The obtained results were further adjusted to an absolute proviral quantification by considering the leukocyte counts per $\mathrm{mm}^{3}$, and the results were expressed as DNA proviral copies $/ \mathrm{mm}^{3}$.

\section{Genotyping of IFNG+874 A/T (rs2430561)}

IFNG $+874 \mathrm{~A} / \mathrm{T}$ polymorphism located in the first intron of the gene encoding IFN- $\gamma$ was analyzed by real-time PCR using a StepOnePLUS ${ }^{\mathrm{TM}}$ Real-Time PCR system. The specific primers (IFNG-F: $5^{\prime}$-TTC AGA CAT TCA CAA TTG ATT TTA TTC T-3' and IFNG-R: 5'-CCC CCA ATG GTA CAG GTT TC- $3^{\prime}$ ) and probes (FAM-AAAATCAAATCTCACACACACAMGB and VIC-AAAATCAAATCACACACACACA-MGB) were previously described (Tso et al., 2005). The reaction followed a 
program of $10 \mathrm{~min}$ at $95^{\circ} \mathrm{C}, 40 \mathrm{cycles}$ of $15 \mathrm{~s}$ at $95^{\circ} \mathrm{C}$ and $1 \mathrm{~min}$ at $60^{\circ} \mathrm{C}$.

\section{Quantification of Plasma IFN- $\boldsymbol{\gamma}$ Levels}

Plasma IFN- $\gamma$ levels were measured by the Ready-SET-Go ${ }^{\circledR}$ enzyme-linked immunosorbent assay (ELISA) (eBioscience, San Diego, CA, United States), which uses specific monoclonal antibodies to detect the cytokine following the manufacturer's instructions.

\section{Statistical Analysis}

Genotype and allele frequencies were estimated by direct counting. Significant differences between groups were determined using the chi-squared test. Hardy-Weinberg equilibrium was calculated to evaluate whether the distribution of the genotype frequencies observed was in agreement with the expected frequencies. Plasma IFN- $\gamma$ levels were compared between groups using the non-parametric Mann-Whitney test. All tests were performed using the software BioEstat 5.3 (Ayres et al., 2011). Statistical associations at p-values $<0.05$ were considered statistically significant.

\section{Ethical Considerations}

The project was approved by the Research Ethics Committee of the João de Barros Barreto University Hospital of the Federal University of Pará (protocol no. 2061/2005). All study participants were fully informed of the research objectives, and those who agreed to participate signed an informed consent form.

\section{RESULTS}

The majority of HTLV-1-infected individuals were female (69.9\%, 107/153), with a mean age of 50.3 years. The frequency of the wild-type genotype was higher in the infected group, but there was no significant difference between the genotype and allele frequencies when compared to the control group (Table 1).

Comparison of genotype frequencies between infected (asymptomatic) and diseased (symptomatic) individuals showed no significant differences. However, the presence of the $\mathrm{T}$ allele was significantly higher $(p=0.0142$ ) among asymptomatic individuals than among diseased patients (Table 2).

TABLE 1 | Genotype and allele frequencies of the IFNG +874 A/T polymorphism among HTLV-1-infected individuals and the control group.

\begin{tabular}{lcccc}
\hline Genotypes and alleles & HTLV & & Control & \multirow{2}{*}{$\boldsymbol{p}^{*}$} \\
\cline { 2 - 3 } & $\boldsymbol{n} n$ & & \\
\hline AA & $83(54.25)$ & & $174(58.00)$ & 0.5153 \\
AT & $58(37.91)$ & & $110(36.67)$ & \\
TT & $12(7.84)$ & & $16(5.33)$ & \\
$*$ A & 0.73 & 0.76 & 0.7456 \\
$*$ *T & 0.27 & 0.24 & \\
\hline
\end{tabular}

$n$, number of individuals; * chi-squared $\left(\chi^{2}\right)$ test.
Plasma IFN- $\gamma$ levels were significantly higher $(p=0.0137)$ in the group with the TT genotype (Figure 1A); they also showed a higher proviral load, although this difference was not statistically significant when compared with the other genotypes (Figure 1B). The proviral load was significantly higher $(p=0.0002)$ among the HAM/TSP patients than among asymptomatic individuals (Figure 1C). No significant difference in plasma levels was observed between patients with the wild-type genotype and those with the polymorphic allele in the symptomatic group (Figure 2A), and no significant difference was observed when comparing patients with the wild-type genotype and those with TSP/HAM or those with rheumatic disease (Figures 2C,D). However, there was a significant difference among the asymptomatic HTLV-1-infected individuals: IFN- $\gamma$ plasma levels among patients with the $T$ allele were significantly higher $(p=0.0016)$ and reached values that were similar to those exhibited by symptomatic individuals (Figure 2B).

\section{DISCUSSION}

The immunological response elicited by HTLV-1-infected individuals appears to be influenced and modulated by the virus, as its presence may promote the spontaneous proliferation of $\mathrm{T} \mathrm{CD}^{+}$and $\mathrm{T} \mathrm{CD}^{+}$lymphocytes and induce the production of proinflammatory cytokines responsible for the symptoms of various diseases, such as HAM/TSP (Goon et al., 2002). Along with other cytokines involved in this process, IFN- $\gamma$ is likely the most important in the immunological pathogenesis of HAM/TSP (Montanheiro et al., 2009), and genetic alterations in its gene sequence lead to an exacerbated inflammatory process and an increase in the severity of the disease.

In the present study, the IFNG $+874 \mathrm{~A} / \mathrm{T}$ polymorphism was not associated with susceptibility to HTLV-1 infection; there was no significant difference in genotype or allele frequencies between HTLV-1-infected individuals and those in the control group. However, the polymorphic allele was associated with the absence of symptoms in HTLV-1-infected individuals. The wildtype allele was already associated as a risk factor for HIV-1 infection (Freitas et al., 2015) and for the disease progression of hepatitis B (Al Kadi and Monem, 2017). The results obtained herein with the allele frequencies suggest that the $\mathrm{T}$ allele would

TABLE 2 | Genotype and allele frequencies of the IFNG +874 A/T polymorphism among symptomatic and asymptomatic HTLV-1-infected individuals.

\begin{tabular}{lcccc}
\hline Genotypes and alleles & Symptomatic & & Asymptomatic & \multirow{2}{*}{$\boldsymbol{p}^{*}$} \\
\cline { 2 - 3 } & $\boldsymbol{n}(\%)$ & & $\boldsymbol{n}(\%)$ & \\
\hline AA & $34(58.63)$ & & $49(51.58)$ & 0.6689 \\
AT & $19(32.75)$ & & $39(41.05)$ & \\
TT & $5(8.62)$ & & $7(7.37)$ & \\
*A & 0.87 & & 0.72 & 0.0142 \\
$* T$ & 0.13 & & 0.28 & \\
\hline
\end{tabular}

n, number of individuals; * chi-squared $\left(\chi^{2}\right)$ test. 

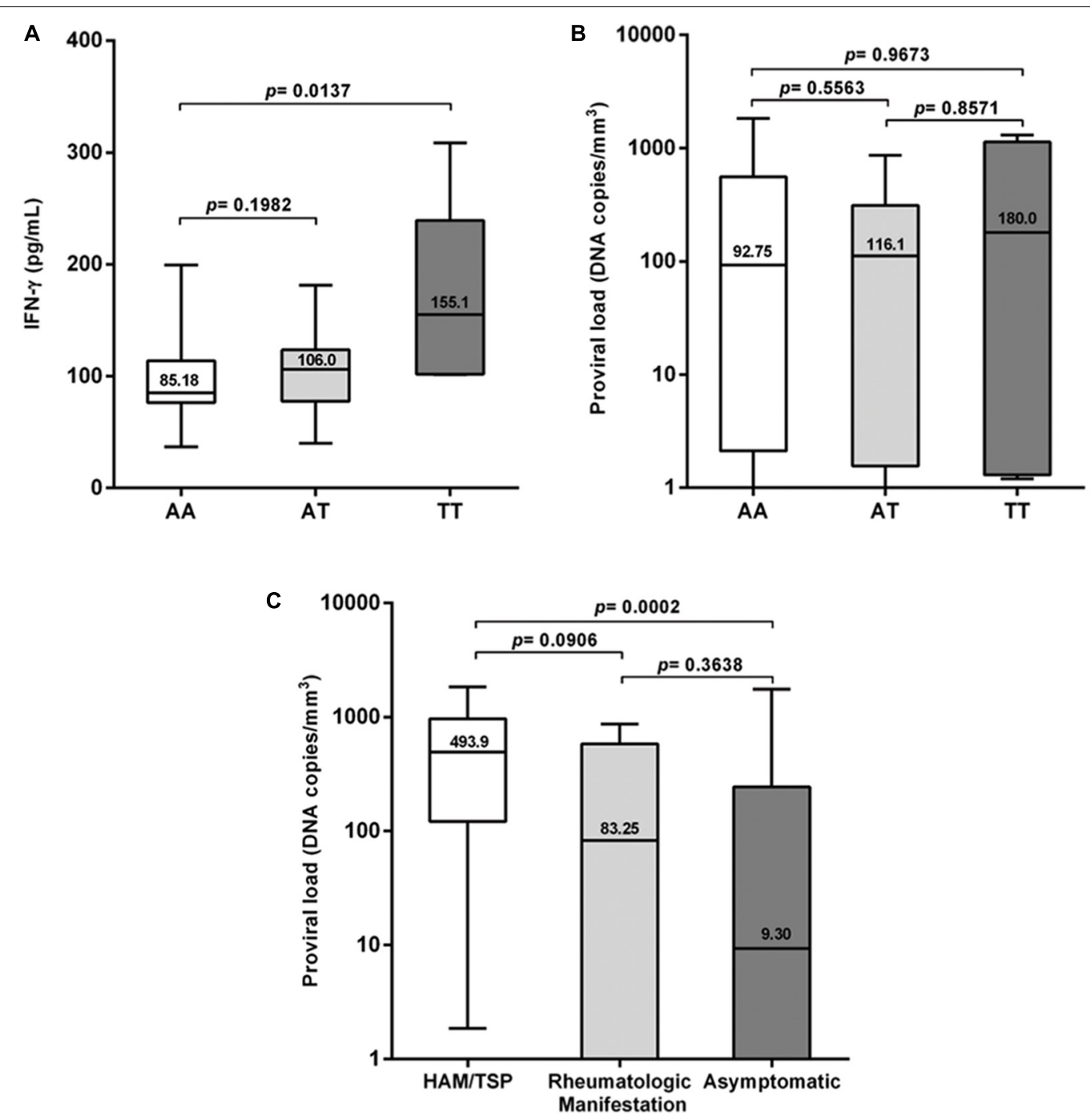

FIGURE 1 | (A) IFN- $\gamma$ plasma levels classified according to IFNG +874 A/T genotypes, (B) proviral load among HTLV-1-infected individuals expressing IFNG +874 AVT genotypes, and (C) proviral load classified according to the presence or absence of symptoms. Mann-Whitney test.

act as a protective factor against the progression to disease among HTLV-1-infected individuals.

These results were not correlated with IFN- $\gamma$ levels measured in plasma. Plasma IFN- $\gamma$ levels were significantly higher among individuals carrying the IFNG $+874 \mathrm{~T}$ allele (genotypes AT and TT); these individuals also showed a higher proviral load, although the differences were not statistically significant. The presence of the polymorphism may increase the levels of inflammation and lead to disease progression. Elevated IFN- $\gamma$ levels in patients with HAM/TSP have previously been associated with central nervous system inflammatory disorders (Yamano et al., 2009).

Proviral load was higher in the patient group; however, in contrast to a previous report from Yakova et al. (2005), the plasma proviral loads of patients with rheumatic disease were higher than those of asymptomatic individuals but lower than those of TSP/HAM patients. Statistical significance was achieved only when HAM/TSP patients were compared with asymptomatic carriers of the virus.

The polymorphism did not affect plasma IFN- $\gamma$ levels among symptomatic patients when they were assessed according to the clinical presentation of the disease or in the presence of the enhanced inflammatory process involving the nervous tissue and joints, as observed among patients with HAM/TSP and rheumatoid arthritis. Several other factors have been associated with the severity of disease, which may be more relevant than the presence of the IFNG $+874 \mathrm{~A} / \mathrm{T}$ polymorphism in this situation (Ahuja et al., 2007; Quaresma et al., 2015).

A significantly different situation was observed with the comparison of IFN- $\gamma$ levels in the asymptomatic group. Individuals carrying the polymorphic allele showed significantly higher levels of IFN- $\gamma$ than those carrying the wild-type allele. This may represent a previously unidentified risk factor for disease progression, as these infected individuals show IFN- $\gamma$ 


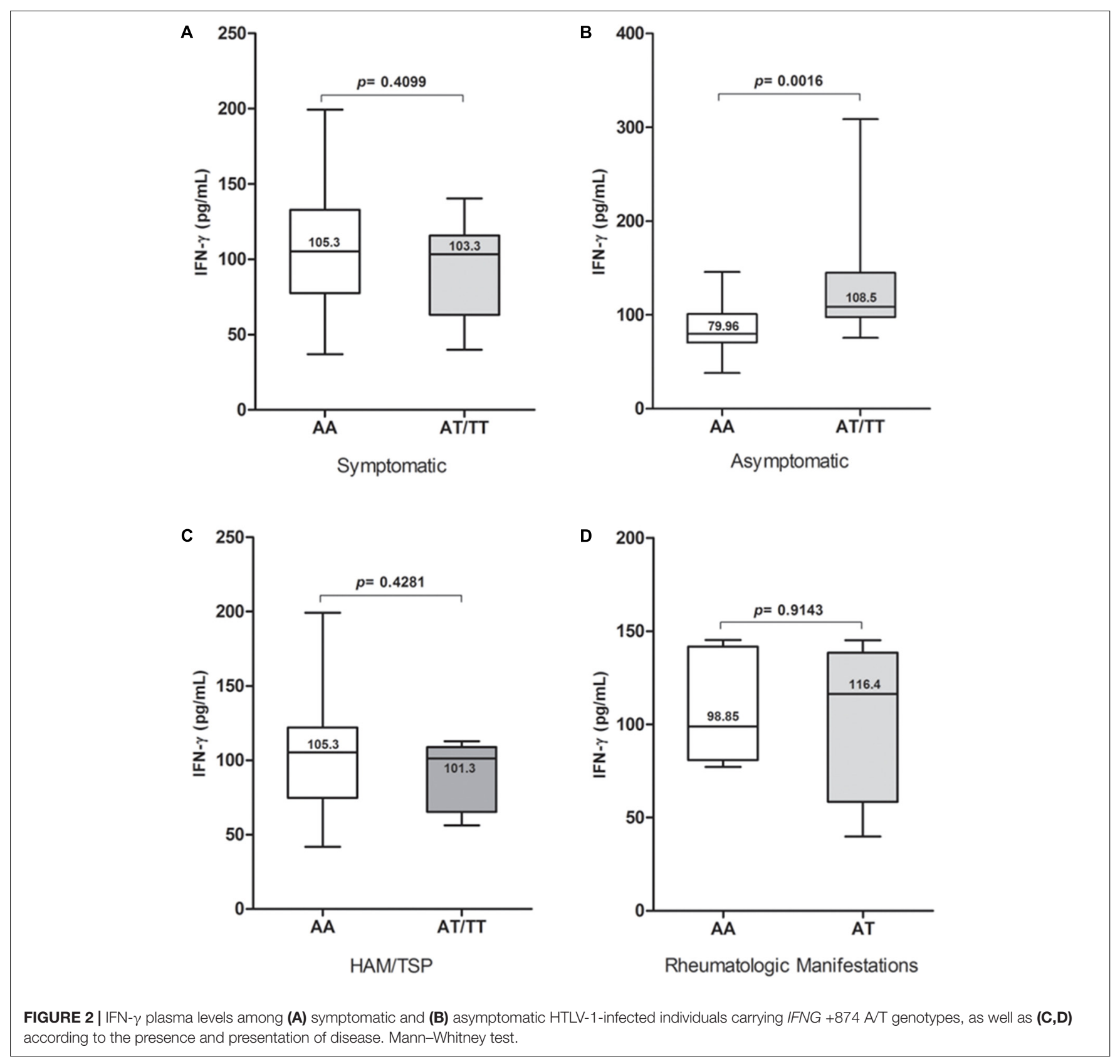

levels similar to those of symptomatic individuals. The proviral load was occasionally detected, and the increase in IFN- $\gamma$ levels may serve as a safe, reliable immunological marker of a poor prognosis and the evolution of disease pathogenesis, which may indicate clinical progression to HAM/TSP (Montanheiro et al., 2009; da Silva Dias et al., 2016).

Although the proviral load is reportedly elevated among HTLV-1-infected individuals with neurological dysfunction (Silva et al., 2007; Grassi et al., 2011), several asymptomatic individuals may present a pattern of immunological response that is associated with a high proviral load (Coutinho et al., 2014) and an inflammatory response similar to those with HAM/TSP (Santos et al., 2004).
Another investigation of the IFNG $+874 \mathrm{~A} / \mathrm{T}$ polymorphism, albeit one that did not measure the intensity of the inflammatory process (using the IFN- $\gamma$ levels as a marker of inflammation), showed that the AT genotype was associated with a higher proviral load (Rocha-Júnior et al., 2012). This suggests that asymptomatic HTLV-1-infected individuals with the $\mathrm{T}$ allele of IFNG $+874 \mathrm{~A} / \mathrm{T}$ and a high proviral load have a high probability of developing HTLV-1-associated inflammatory diseases.

The immunological response during HTLV-1 infection is complex, and although IFN- $\gamma$ is crucial in fighting intracellular viral agents by blocking their replication (Schoenborn and Wilson, 2007), elevated levels of this cytokine are harmful to the 
host; in the case of HTLV-1, this may lead to the progression of severe diseases, including HAM/TSP.

\section{CONCLUSION}

The present results suggest that the IFNG +874 A/T polymorphism may influence IFN- $\gamma$ plasma levels upon HTLV1 infection. Asymptomatic individuals carrying the $\mathrm{T}$ allele appear to be more likely to develop inflammation more rapidly, which could lead to the onset of associated diseases. The present investigation identifies IFN- $\gamma$ levels and its sequence polymorphism as an important biomarker to be further investigated and monitored among HTLV-1-infected patients as part of the routine follow-up of asymptomatic individuals, as they are potentially at risk of developing a worse prognosis of disease and should start available treatment procedures earlier.

\section{REFERENCES}

Ahuja, J., Lepoutre, V., Wigdahl, B., Khan, Z. K., and Jain, P. (2007). Induction of pro-inflammatory cytokines by human T-cell leukemia virus type-1 Tax protein as determined by multiplexed cytokine protein array analyses of human dendritic cells. Biomed. Pharmacother. 61, 201-208. doi: 10.1016/j.biopha.2007. 02.006

Al Kadi, M., and Monem, F. (2017). Polymorphism of IFN- $\gamma(+874$ T/A) in Syrian patients wit/h chronic hepatitis B. Gastroenterol. Hepatol. Bed Bench 10, 34-38.

Araya, N., Sato, T., Ando, H., Tomaru, U., Yoshida, M., Coler-Reilly, A., et al. (2014). HTLV-1 induces a Th1-like state in CD4+CCR4+ T cells. J. Clin. Invest. 124, 3431-3442. doi: 10.1172/JCI75250

Ayres, M., Ayres, J. R., Ayres, D. L., and Santos, A. S. (2011). BioEstat 5.3: Aplicações Estatísticas nas Areas das Ciências Biológicas e Médicas. Belém: Editora Sociedade Civil Mamirauá, 364.

Best, I., López, G., Verdonck, K., González, E., Tipismana, M., Gotuzzo, E., et al. (2009). IFN-gamma production in response to Tax 161-233, and frequency of CD4+ Foxp3+ and Lin HLA-DRhigh CD123+ cells, discriminate HAM/TSP patients from asymptomatic HTLV-1-carriers in a Peruvian population. Immunology 128, e777-e786. doi: 10.1111/j.1365-2567.2009.03082.x

Brasil. Ministério da Saúde (2013). Guia de Manejo Clínico da Infecção pelo HTLV. Available at: http://www.sierj.org.br/artigos/htlv_manual_final_pdf_25082.pdf

Cassar, O., and Gessain, A. (2017). Serological and molecular methods to study epidemiological aspects of human T-cell lymphotropic virus type 1 infection. Methods Mol. Biol. 1582, 3-24. doi: 10.1007/978-1-4939-6872-5_1

Catalan-Soares, B., Carneiro-Proietti, A. B. F., and Proietti, F. A. (2005). Heterogeneous geographic distribution of human T-cell lymphotropic viruses I and II (HTLV-I/II): serological screening prevalence rates in blood donors from large urban areas in Brazil. Cad. Saúde Pública 21, 926-931. doi: 10.1590/S0102311X2005000300027

Coutinho, R. Jr., Grassi, M. F., Korngold, A. B., Olavarria, V. N., Galvão-Castro, B., and Mascarenhas, R. E. (2014). Human T lymphotropic virus type 1 (HTLV1) proviral load induces activation of T-lymphocytes in asymptomatic carriers. BMC Infect. Dis. 14:453. doi: 10.1186/1471-2334-14-453

da Silva Dias, G. A., Sousa, R. C. M., Gomes, L. F., Caldas, C. A. M., Nassiri, R., Quaresma, J. A. S., et al. (2016). Correlation between clinical symptoms and peripheral immune response in HAM/TSP. Microb. Pathog. 92, 72-75. doi: 10.1016/j.micpath.2015.11.018

de Sá, K. S., Santana, B. B., de Souza Ferreira, T. C., Sousa, R. C., Caldas, C. A., Azevedo, V. N., et al. (2016). IL28B gene polymorphisms and Th1/Th2 cytokine levels might be associated with HTLV-associated arthropathy. Cytokine 77, 79-87. doi: 10.1016/j.cyto.2015.11.004

Freitas, F. B., Lima, S. S., Feitosa, R. N., Azevedo, V. N., Ishak, M. O., Ishak, R., et al. (2015). Polymorphisms in the IFN $\gamma$, IL-10, and TGF $\beta$ genes may be associated with HIV-1 infection. Dis. Markers 2015:248571. doi: 10.1155/2015/ 248571

\section{AUTHOR CONTRIBUTIONS}

MQ, RI, AV, and RM designed the study, analyzed and interpreted the data. MQ, VA, EA, and TM performed the experiments. MQ wrote the manuscript. MG, RI, and AV oversaw the experiments and edited the manuscript. MQ, VA, EA, TM, MG, RI, AV and $\mathrm{RM}$ reviewed the manuscript.

\section{FUNDING}

The present study was fully supported by grants from the Conselho Nacional de Desenvolvimento Científico e Tecnológico - CNPq (Grant No. 302582/2013-4) and the Universidade Federal do Pará. The funding source(s) had no involvement in conducting the research and/or preparing the article.

Gessain, A., and Cassar, O. (2012). Epidemiological aspects and world distribution of HTLV-1 infection. Front. Microbiol. 3:388. doi: 10.3389/fmicb.2012.00388

Goon, P. K., Hanon, E., Igakura, T., Tanaka, Y., Weber, J. N., Taylor, G. P., et al. (2002). High frequencies of Th1-type CD4(+) T cells specific to HTLV-1 Env and Tax proteins in patients with HTLV-1-associated myelopathy/tropical spastic paraparesis. Blood 99, 3335-3341. doi: 10.1182/blood.V99.9.3335

Goon, P. K., Igakura, T., Hanon, E., Mosley, A. J., Barfield, A., Barnard, A. L., et al. (2004). Human T cell lymphotropic virus type I (HTLV-I)-specific CD4+ T cells: immunodominance hierarchy and preferential infection with HTLV-I. J. Immunol. 172, 1735-1743. doi: 10.4049/jimmunol.172.3.1735

Grassi, M. F., Olavarria, V. N., Kruschewsky, R. d. A, Mascarenhas, R. E., Dourado, I., Correia, L. C., et al. (2011). Human T cell lymphotropic virus type 1 (HTLV-1) proviral load of HTLV-associated myelopathy/tropical spastic paraparesis (HAM/TSP) patients according to new diagnostic criteria of HAM/TSP. J. Med. Virol. 83, 1269-1274. doi: 10.1002/jmv.22087

Kato, T., Asahara, H., Kurokawa, M. S., Fujisawa, K., Hasunuma, T., Inoue, H., et al. (2004). HTLV-I env protein acts as a major antigen in patients with HTLVI-associated arthropathy. Clin. Rheumatol. 23, 400-409. doi: 10.1007/s10067004-0901-z

Montanheiro, P. A., Penalva de Oliveira, A. C., Smid, J., Fukumori, L. M., Olah, I., da S Duarte, A. J., et al. (2009). The elevated interferon gamma production is an important immunological marker in HAM/TSP pathogenesis. Scand. J. Immunol. 70, 403-407. doi: 10.1111/j.1365-3083.2009.02291.x

Okajima, R., Oliveira, A. C., Smid, J., Casseb, J., and Sanches, J. A. Jr. (2013). High prevalence of skin disorders among HTLV-1 infected individuals independent of clinical status. PLoS Negl. Trop. Dis. 7:e2546. doi: 10.1371/journal.pntd. 0002546

Pinto, L. A., Galvão Castro, B., Soares, M. B., and Grassi, M. F. (2011). An evaluation of the spontaneous proliferation of peripheral blood mononuclear cells in HTLV-1-infected individuals using flow cytometry. ISRN Oncol. 2011:326719. doi: 10.5402/2011/326719

Pombo de Oliveira, M. S., Loureiro, P., Bittencourt, A., Chiattone, C., Borducchi, D., De Carvalho, S. M., et al. (1999). Geographic diversity of adult T-cell leukemia lymphoma in Brazil. The Brazilian ATLL Study Group. Int. J. Cancer 83, 291-298. doi: 10.1002/(SICI)1097-0215(19991029)83:3<291::AIDIJC1>3.0.CO;2-P

Pravica, V., Asderakis, A., Perrey, C., Hajeer, A., Sinnott, P. J., and Hutchinson, I. V. (1999). In vitro production of IFN-gamma correlates with CA repeat polymorphism in the human IFN-gamma gene. Eur. J. Immunogenet. 26, 1-3. doi: 10.1046/j.1365-2370.1999.00122.x

Quaresma, J. A., Yoshikawa, G. T., Koyama, R. V., Dias, G. A., Fujihara, S., and Fuzii, H. T. (2015). HTLV-1, immune response and autoimmunity. Viruses 8:5. doi: $10.3390 / \mathrm{v} 8010005$

Rathsam-Pinheiro, R. H., Boa-Sorte, N., Castro-Lima-Vargens, C., Pinheiro, C. A., Castro-Lima, H., and Galvão-Castro, B. (2009). Ocular lesions in HTLV-1 infected patients from Salvador, State of Bahia: the city with the highest 
prevalence of this infection in Brazil. Rev. Soc. Bras. Med. Trop. 42, 633-637. doi: 10.1590/S0037-86822009000600004

Rocha-Júnior, M. C., Haddad, R., Cilião Alves, D. C., de Deus Wagatsuma, V. M., Mendes-Junior, C. T., Deghaide, N. H., et al. (2012). Interleukin-18 and interferon-gamma polymorphisms are implicated on proviral load and susceptibility to human T-lymphotropic virus type 1 infection. Tissue Antigens 80, 143-150. doi: 10.1111/j.1399-0039.2012.01887.x

Santos, S. B., Porto, A. F., Muniz, A. L., de Jesus, A. R., Magalhães, E., Melo, A., et al. (2004). Exacerbated inflammatory cellular immune response characteristics of HAM/TSP is observed in a large proportion of HTLV-I asymptomatic carriers. BMC Infect. Dis. 4:7. doi: 10.1186/1471-2334-4-7

Schoenborn, J. R., and Wilson, C. B. (2007). Regulation of interferon-gamma during innate and adaptive immune responses. Adv. Immunol. 96, 41-101. doi: 10.1016/S0065-2776(07)96002-2

Shirdel, A., Azarpazhooh, M. R., Sahebari, M., Ghanbari, M., Mirfeizi, S. Z., Hutchinson, I., et al. (2013). Association of IL-10 gene polymorphisms and human $\mathrm{T}$ lymphotropic virus type I-associated myelopathy/tropical spastic paraparesis in North-East of Iran (Mashhad). Iran J. Basic Med. Sci. 16, 258-263.

Silva, M. T., Harab, R. C., Leite, A. C., Schor, D., Araújo, A., and AndradaSerpa, M. J. (2007). Human T lymphotropic virus type 1 (HTLV-1) proviral load in asymptomatic carriers, HTLV-1-associated myelopathy/tropical spastic paraparesis, and other neurological abnormalities associated with HTLV-1 infection. Clin. Infect. Dis. 44, 689-692. doi: 10.1086/510679

Tamegão-Lopes, B. P., Rezende, P. R., Maradei-Pereira, L. M. C., and Lemos, J. A. R. (2006). HTLV-1 and HTLV-2 proviral load: a simple method using quantitative real-time PCR. Rev. Soc. Bras. Med. Trop. 39, 548-552. doi: 10.1590/S003786822006000600007
Tso, H. W., Ip, W. K., Chong, W. P., Tam, C. M., Chiang, A. K., and Lau, Y. L. (2005). Association of interferon gamma and interleukin 10 genes with tuberculosis in Hong Kong Chinese. Genes Immun. 6, 358-363. doi: 10.1038/sj. gene.6364189

Vallinoto, A. C., Santana, B. B., dos Santos, E. L., Santo, R. R., Hermes, R. B., Sousa, R. C., et al. (2012). FAS-670A/G single nucleotide polymorphism may be associated with human T lymphotropic virus-1 infection and clinical evolution to TSP/HAM. Virus Res. 163, 78-82. doi: 10.1016/j.virusres.2011.09.015

Yakova, M., Lézin, A., Dantin, F., Lagathu, G., Olindo, S., Jean-Baptiste, G., et al. (2005). Increased proviral load in HTLV-1-infected patients with rheumatoid arthritis or connective tissue disease. Retrovirology 2:4. doi: 10.1186/17424690-2-4

Yamano, Y., Araya, N., Sato, T., Utsunomiya, A., Azakami, K., Hasegawa, D., et al. (2009). Abnormally high levels of virus-infected IFN-gamma+ CCR4+ CD4+ $\mathrm{CD} 25+\mathrm{T}$ cells in a retrovirus-associated neuroinflammatory disorder. PLoS One 4:e6517. doi: 10.1371/journal.pone.0006517

Conflict of Interest Statement: The authors declare that the research was conducted in the absence of any commercial or financial relationships that could be construed as a potential conflict of interest.

Copyright (c) 2018 Queiroz, Azevedo, Amoras, Moura, Guimarães Ishak, Ishak, Vallinoto and Martins Feitosa. This is an open-access article distributed under the terms of the Creative Commons Attribution License (CC BY). The use, distribution or reproduction in other forums is permitted, provided the original author(s) and the copyright owner are credited and that the original publication in this journal is cited, in accordance with accepted academic practice. No use, distribution or reproduction is permitted which does not comply with these terms. 